\title{
Resurrecting the Go-Between: A Study of the Revived Bawd's Challenge to Blood Purity and Christian Doctrine in Feliciano de Silva's Segunda comedia de la Celestina
}

\author{
Andrea Nate \\ University of North Alabama
}

\begin{abstract}
This study argues that Feliciano de Silva's Segunda comedia de la Celestina (1534) challenges officially mandated religious homogeneity through the figure of the go-between. Each section of the article traces the strategies of resistance of the resurrected Celestina in dialogue with Silva's connections to the converso community. A comparative, historicist approach shows how the author implicates the text in a greater discourse associated with Inquisitorial practices. I ultimately contend that the intermediary, when studied beside the woodcuts in the oldest surviving rare edition of the text, Medina del Campo 1534, operates in ways that resist notions of contamination. By examining the ways in which Silva inverts paradigms through the go-between protagonist, this study reveals how the sequel calls into question prevailing attitudes toward limpieza de sangre in sixteenth-century Spain. Finally, engaging with several theories about La Celestina's possible functions, sheds light on how sixteenth-century readers may have read the original bestselling comedy.
\end{abstract}

KEY WORDS: La Segunda comedia de la Celestina.The Go-between.

Resucitando a la alcahueta: un estudio del desafío a la pureza de sangre y la doctrina cristiana del personaje de la medianera revivida en la Segunda comedia de la Celestina de Feliciano de Silva

\section{RESUMEN}

En este artículo argumento que la resurrección de la Celestina cuestiona la noción de la pureza de sangre, así como ciertos aspectos de la doctrina cristiana que la población conversa se veía obligada a reconocer oficialmente. Comparo la secuela de Silva con las escenas de resurrección en varias obras literarias medievales, así como las de ciertos textos de contemporáneos suyos. Concluyo que Silva invierte el motivo de la resurrección milagrosa, utilizándolo como punto de partida no 
sólo para continuar el argumento de La Celestina, sino también para recoger varias posibles funciones de la Comedia de Calisto y Melibea y la Tragicomedia de Calisto y Melibea. Tras analizar los grabados en la edición de Medina del Campo 1534, el lenguaje y el contexto histórico, muestro que Segunda Celestina, a través de la alcahueta resucitada, parece recoger la crítica social y la interrogación de varios paradigmas literarios, religiosos y culturales que parecen llevar a cabo la Comedia y Tragicomedia originales. Por último, propongo que la secuela, leída de cierto modo al lado de La Celestina, nos ayuda a entender la recepción de la alcahueta famosa y su vinculación con cuestiones de la marginación social.

palabras ClaVE: La Segunda comedia de la Celestina. La alcahueta.

Feliciano de Silva's Segunda Comedia de la Celestina (1534) likely surprised sixteenth-century La Celestina readers. ${ }^{1}$ Whereas in the original tragicomedy Pármeno and Sempronio supposedly murdered the alcahueta, Silva's sequel presupposes that her death had been a farce. Having staged her murder by hiding in a bishop's house, the bawd now feigns revival and convinces the other characters that, while in hell, she sharpened her skills in black magic. Beneath the clear differences between the two original texts and the sequel lie more nuanced discrepancies and similarities, which are nonetheless crucial to the text's hermeneutics. The following study argues that Celestina's resurrection may point to a broader concern with blood purity and the widespread socio-political instability that characterized Silva's lifetime (1491-1554). Indeed, the sequel appears to challenge, through the resuscitated intermediary figure who operates in ways that resist notions of contamination, the officially mandated religious homogeneity that drastically altered late medieval/early modern Spain's demographics. By examining the ways in which the sequel inverts the Christian resurrection paradigm through the go-between protagonist, this article reveals how the text calls into question prevailing contemporaneous attitudes toward limpieza de sangre. In turn, further understanding how sixteenth-century authors appropriated the now canonical La Celestina may shed light on the original bestseller's possible functions.

Recent critical discussion of Silva's text has focused on other legal questions, as well as the sequel genre. Yolanda Iglesias reads a denunciation of ecclesiastic and familial control of marriage in the work ("Aspectos legales y sociales del matrimonio» 467). For his part, William Hinrichs studies Silva's revival of Celestina as a restoration of her reputation (59-93). Studies arguing that many late medieval literary works challenge the Spanish state's legal and social imposition of orthodoxy have also been influential for this article. Francisco Márquez's cases for Semitic origins

1.- Unless noted otherwise, throughout this article La Celestina refers to the twenty-one act Tragicomedia de Calisto y Melibea (1502). 
in early Spanish literature included studies that emphasized the alcahueta's converso discourse (Orígenes y sociología 142). Furthermore, Gregory Kaplan explains that certain texts written by conversos interrogate Inquisitorial proceedings, in addition to fifteenth-century treatment of Jewish and Muslim converts to Christianity and their descendants. These include Diego San Pedro's Cárcel de amor (1492), the poetry of Rodrigo Cota (d. 1498), and La Celestina. Aside from his work on the erotic connotations of weaving in La Lozana andaluza, in his 2005 monograph The Art of Subversion in Inquisitorial Spain: Rojas and Delicado, Manuel da Costa Fontes explores the encoded attacks against Christian dogma in the $\mathrm{La}$ Celestina and Delicado's narrative.

Despite these and other influential works, a close reading of Segunda Celestina has yet to form part of the dialogue on blood purity in early modern Spanish literature. Additionally, scholars have not discussed the visual function of Celestina's return from the dead, nor have critics concerned themselves with the book's material history. Paying attention to such aspects in relation to the text's history with censorship is important because doing so may shed light on the work's reception and the threat that its themes could have posed to certain fundamental Christian tenets. To address these gaps in the literature, I situate my reading of Silva's sequel within the ongoing dialogue on blood purity's influence on late medieval and Golden Age Spanish literature, in addition to drawing upon recent work on the material history of the early modern Spanish book. A comparative approach to Segunda Celestina will demonstrate how the sequel responds to varied literary and iconographic traditions and achieves a challenge to hierarchies. I begin by commenting on Celestina's return and censoring authorities' reactions to both La Celestina and Segunda Celestina. Next, a comparison will be made to Alfonso X's Cantigas de Santa María (1221-1284), El Libro de Apolonio (c.1250), El Libro del caballero Zifar (c.1300), and La relación que dio Álvar Núñez Cabeza de Vaca (1542): four works that demonstrate a long-standing tradition of the resurrection motif with which Silva's text contrasts. Indeed, Silva appears to capitalize on the Christian resurrection trope, which appears in multiple types of texts whose objectives are different from his. Finally, this study relates the xylographs in the oldest surviving copy of the text, the Hispanic Society of America's Medina del Campo 1534 edition, to Silva's treatment of Christian and non-Christian heritage in Spain. A study of the prints in the earliest extant copy of the text helps evince how Silva's contemporaries likely received the sequel. This approach also reveals the ways in which the text visually questions literary models and encrypts a twofold challenge: first, to the dominant Catholicism forced on New Christians, and second, to the institution of limpieza de sangre.

Although Rojas's authorship remains debated, this article considers the possibility of its veracity, at least partially. Accepting this theory, in turn, 
proves valuable for understanding how Segunda Celestina appears to appropriate La Celestina's commentary on specific social issues within the context of Spain at the turn of the sixteenth century. Both Rojas and Silva were connected to the converso community. Scholars have debated the former writer's alleged Jewish ancestry and its possible influence on the text. José Luis Canet argues that Rojas was little involved, if at all. By contrast, Stephen Gilman argued that Rojas's authorship, as well as his converso identity, greatly impacted La Celestina's tragic themes. On the other hand, Peter Russell's theory reminds us that, while there is no solid proof that the Inquisition persecuted Rojas or his immediate family, as a fourth-generation converso whose father-in-law the Holy Office had infamously tried twice, Rojas must have been wary that his seemingly comfortable professional and social situation could change at any moment (33, 37-38). While one cannot prove that Silva associated Rojas directly with La Celestina or with the converso community, Segunda Celestina's author maintained a similar, indirect connection with New Christians: both he and Rojas shared ties to tainted Christianness through their wives' backgrounds. Although Silva hailed from a distinguished Old Christian family, he was connected to converso circles through marriage and friendship: two details that may partly explain the sequel's treatment of precariousness in his sequel. Consolación Baranda cites converso Jorge Montemayor's elegy to Silva upon his death as well as exiled converso Núñez de Reinoso's nostalgic verses of his Égloga Baltea to our author as evidence of his sympathy toward the New Christian community (32). Additionally, she summarizes that authorities denied Silva's grandson, Fernando de Toledo y Silva, admittance to the Order of Santiago on the basis of his possible converso lineage through his grandmother, while other officials claimed that Silva's wife was the illegitimate daughter of a noble (31). In either case, similar to how Rojas's family progeny inherited an ancestral infamy, a stain marked Silva's descendants. By contextualizing both authors' writing and their family stories, we can understand how lineage-based discrimination crossed social classes, affecting conversos in relatively comfortable or powerful positions, or individuals whose political stances went against the grain. ${ }^{2}$ Both Silva's and Rojas's converso ties are, thus, significant for understanding this article's contention that Segunda Celestina responds to La Celestina beyond merely continuing the bawd's story. Indeed, judging by the resonances between Rojas's and Silva's ex-

2.- One example is the anti-Inquisitorial views of conversos such as the Hieronymite friar Hernando de Talavera, whose tolerance of the Granadan mudéjares sparked conflict with Cisneros (Harvey, Muslims in Spain 329). Another example is the 1522 Decree of Suprema that prohibited universities from granting degrees to converso and descendants of those tried by the Inquisition (Lea, A History of the Inquisition 287). These are a few of the many examples of conflicting stances on forced conversion that may figure into the context of Silva's writin 
periences, the social commentary that we read in La Celestina may function as an essential thematic bridge to Silva's sequel.

This article also engages with recent scholarship that argues that both the 1499 Comedia de Calisto y Melibea and 1502 Tragicomedia de Calisto y Melibea (La Celestina) question paradigms. Proposing that a team of seasoned intellectuals — rather than a single student- composed the Comedia as a censure of the scholastic oral or written disputa in which interlocutors ceded all intellectual thought to florilegios and authorities, Canet reminds us that the continuation of the first act coincided with the $\mathrm{Hu}-$ manist reformation of the University of Salamanca (26-29). ${ }^{3}$ He further determines that Celestina and her fellow socially marginalized characters engage in a parodied version of the disputa, since they speak as though they were philosophers (66). Canet proposes that through a paradoxically erudite Celestina, Sempronio, Calisto, and Pármeno, the team of university intellectuals who must have written the comedy ridiculed medieval scholasticism. It follows, then, that Renaissance intellectuals chose the go-between as protagonist of a text aimed at modifying the Castilian university by defying the established authority on education. Accordingly, the team of intellectuals responsible for the Comedia ridiculed what they considered to be outdated modes of inquiry through an ironically learned alcahueta. Similarly, Yolanda Iglesias argues that La Celestina parodies the long-standing sentimental fiction genre that had been popular throughout the fifteenth century (Una nueva mirada a la parodia de la novela sentimental 24). The following pages demonstrate how Silva's sequel appropriates this incongruity from both the primitive Comedia and La Celestina.

\section{The Go-Between Resurrected}

To understand how the protagonist's rebirth facilitates the sequel's subversive social criticism and literary contamination, we must recall the original Celestina's death, which launches those of Pármeno, Sempronio, Calisto, and Melibea (Baranda 34). By contrast, Segunda Celestina ties the go-between's fate to her entrance to the comedy instead of her exit. Here she has no dramatic exodus, as she does in the original text. Her final appearance is in the penultimate scene, which is uneventful, save its echo of auto XII in La Celestina in which Celestina and the servant Pandulfo scuffle over money. The bawd's action is most concentrated in the first few cenas, which, while they contain the majority of the sensationalized action in the text, highlight the resurrection's incredulity, such as Celestina's reveal-

3.- Here I reference Jose Luis Canet's edition of the Comedia, instead of the Tragicomedia, in order to emphasize the hypotheses that the fifteen acts that were added to the first auto, among their many functions, serve to dismantle epistemological and literary paradigms such as scholasticism and sentimental fiction. I discussed these theories later in the article. 
ing her scheme to the servant Zenara, "He querido dezirte lo dicho para que no vivas conmigo engañada, porque ya es tiempo de salir a fingir mi resurrección» (Silva 171). Felides further summarizes her trick: "y ella con sus hechizos hizo parescer todo lo passado para se vengar de los criados de Calisto, porque le querían tomar lo que su amo le había dado, y hizo con sus encantamientos parecer que era muerta, y ahora fingió haver ressucitado" (Silva 578). Finally, Polandria reprimands her criada Poncia for believing in the hoax: «¿Cómo diablos dirá lo que no vio? Ora cree que es el diablo, y no otro» (Silva 579). Again, Hinrichs describes the resuscitation as a chivalric reconquest of her hometown, arguing that the protagonist transforms into an archetype that transcends death. He also ties into the themes of impurity via the loss of virginity and thanatos in the La Celestina (68). As valuable as these readings are for highlighting the text's challenge of authority and blood symbolism in the text, they do not consider that the resurrection not only results in Celestina's reconquering the town, but also in the text's overall defiance of Christian dogma and blood purity.

Celestina's deceptive resurrection denounces the atmosphere of fifteenth and sixteenth-century Castile, where appearances was of utmost importance and false rumors spread quickly. The bawd allegedly returns to «enmendar la vida de acá, para con las obras dar el enxemplo con aviso de lo que allá passa, pues la misericordia de Dios fue de bolverme al siglo a hazer penitencia» (Silva 191). Although the reader knows that the resurrection is a farce, the other characters treat the act as a serious miracle. Pandulfo voices the importance of this event: «Señora, agora no se habla de otra cosa sino en tu resurrección» (238), while Felides blasphemously describes the protagonist's return as a miracle (Hinrichs 69). This ironic treatment of hell echoes and surpasses the triviality with which the afterlife is treated in the original La Celestina. Indeed, the original work suggests that many of the main characters are destined for hell as a result of dying without the required Catholic confession.

In addition to clarifying the resurrection's outrageousness, Silva outwardly conforms to orthodoxy by creating characters who appear as redeemed versions of their original counterparts. Consider, for example, Felides's advice to Sigeril: «Dexa ya, Sigeril, la vanidad de dioses vanos, y adora aquel solo que yo por Dios adoro y conozco" (Silva 441). His comments are quite the opposite of Calisto's affirmations that he is more devoted to Melibea than to the Christian God (Penney 128-129). Although Silva apparently evades any true heresy, the Inquisition indexed the book in 1559 (Index 531). By contrast, La Celestina circulated in Castile unhindered by official censoring authorities for more than a century after its original publication (Green, "The Celestina and the Inquisition" 211; "Additional Note» 71). In fact, the Holy Office did not veto Calisto's sacrilegious lines until the seventeenth century and there is no record of La Celestina in the hefty 1557 or 1559 Valdés Indices. Several early six- 
teenth-century efforts to index the text proved unsuccessful (Gagliardi 59-60). Consequently, the oeuvre appears to have remained uncensored until the mid-seventeenth century, when the Sotomayor Index censored some fifty lines, mostly spoken by Calisto in equating Melibea to divinity (Green, «The Celestina and the Inquisition» 211-216; Gagliardi 73-74). La Celestina's sustained evasion of excision thus contrasts with the almost immediate, full suppression of Segunda Celestina. Given the original comedy's early resistance to censorship, Silva, and most readers of the bestseller, may have read the expurgated passages.

While La Celestina side-stepped actual censorship, the tragicomedy did, however, meet widespread disapproval by sixteenth-century Christian moralists (Green, "The Celestina and the Inquisition» 213; Gagliardi 59). Silva's text surpasses such opprobrium, as nowhere is this irreverence more overt than in Celestina's resurrection. The much quicker reaction of censors to Segunda Celestina reveals that sixteenth-century authorities considered her return from the dead a threat to religious orthodoxy. While Hinrichs interprets the resurrection as a kind of chivalric redemption, I maintain that irony, more than heroism, are at play here, and that the sequel disguises serious social criticism in a cloak of satirical sacrilege. Because censoring authorities considered the sequel more heretical than the original text, Silva's book achieves a more aggressive imputation than the original bestseller. Indeed, several characters employ miraculous language to describe Celestina's satirical revival:
AREÚSA: ¡Ay, tía señora!, espantadas nos tienes en ver cuanto dizes[... ¡ ¡Oh, madre Celestina!, ¿qué maravilla tan grande ha sido ésta de tu resurrección?
PUEBLO: Madre, espantados nos tienes de lo que dizes, mucha honra nos harías en decirnos algo de lo que allá viste. (Silva 190-191)

This tone of awe and fear, as well as El Pueblo's desire to hear Celestina's account, parody earlier literary acts of raising the dead. We find, for instance, several medieval examples of language comparable to Segunda Celestina's, such as in Holy Mary's resurrection of two devoted mothers in Alfonso's cantigas. ${ }^{4}$ Cantiga 21 tells the story of a mother who, after her infant dies shortly after birth, takes the lifeless newborn to the monastery, lays him before the altar, and prays to the Blessed Mother, who restores him to life. A Castilian prosified refrain appears after each of the following verses: "Santa María[...] quando ella quesier e muertos resurgir»[...] Ca tu soa es a que mio podes dar[...] groriosa Sennora, sen tardar/dá-mio vivo, que aja que ti gracir[...] menyo tornou en vida/por prazer

4.- The resurrection motif appears in Cantigas 11, 21, 26, 122, 224, 241, and 391. I analyze 21 and 122 for the purpose of focusing on women whom the Virgin restores to life. 
da Virgen santa conprida[...] Quand' esto viu a moller, ouve pavor» (Alfonso, Cantigas de Santa María 113; cantiga 21, vv. 45-59).

Similar examples of resurrection as a kind of reward for Christian feminine devotion appear in cantiga 122, the Libro de Apolonio, and the Libro del Caballero Zifar. Cantiga 122 recounts, "Cómo Santa Maria resucitó a una infanta, hija de un rey, que después fue monja y muy santa mujer» (Alfonso, Cantigas 188). ${ }^{5}$ In this purportedly autobiographical song, Alfonso's mother takes her deceased daughter to the Virgin's chapel where she affirms her faith that the saint will resuscitate her: Mary again revives the dead infant. When, in Libro de Apolonio, the king believes his wife Luciana has died, her companions throw her coffin into the sea. Doctors later rescue her and restore her to life, she then becomes an abbess, and husband and wife's anagnórisis unfolds as follows:

[Apolonio]: Por poco que con gozo non perdió la memoria; amos huno con otro viéronsse en gran gloria,/car auiéles Dios dado grant gracia et gran victoria[...] lloraua de los ojos como ssi fuesse su pradre[...] Por la çibdat de Effesio corrié grant alegría,/auién con esta cosa todos plazentería;/mas llorauan las duenyas dentro de la mongía,/ca sse temién de la sennyora que sse quería yr ssu vía. (Libro de Apolonio 204; vv. 587-597)

Luciana describes the widespread, joyously tearful response to her resurrection, attributing the miracle to the grace of God. Indeed, the scene fits into the Christian model of revival as an accolade for piety. The trope of the resurrected lady remerges in the Libro del caballero Zifar, with the Virgin's miraculous revival of Grima, the lady of the villa Galapia, whose friends mistake her unconsciousness for death (Olsen 21).

Todas las dueñas que y estauan fueron mucho espantadas e maravillaronse[...] vieron a su señora que abrio los ojos e alço las manos ayuntadas contra el çielo e dixo asy: 'Señora, Virgen Santa Maria[...] Ca me tornaste por la tu santa piedat de muerte a vida'[...] Todos los que y estauan oyeron muy bien lo que dezia, e enbiaron mandado a los caualleros de commo su señora era biua. (Libro del caballero Zifar 120)

Areúsa's and Elicia's fearful marveling thus echoes that of Grima's ladies. Like grieving mothers in the Cantigas, both Grima and Luciana are

5.- This selection, which appears as number 21 in Jesús Montoya's edition is cantiga 122 in $E$ and T. Volume I of Mettman's edition, which concludes with cantiga 100, lacks these verses. Volume II was unavailable when I wrote this article. I cite two editions because each contains a different example of a feminine resurrection miracle. 
exemplary Christian —or Christianized ${ }^{6}$ - women, and three of them are model mothers. Luciana's revival results in her assuming a religiously authoritative position. News of her rebirth spread quickly through Effesio igniting tears of joy in many of the kingdom's subjects, as well as fear in the nuns, not unlike the grieving mother's initial "pavor» upon witnessing the miracle in cantiga 21. Grima's resurrection is dually edifying in that Mary, the ultimate model of female sanctity, brings back the exemplary woman, not unlike the way the cantigas make clear that only Mary shares Christ's power to raise the dead. In sum, the Virgin Mary, symbol of Christian maternity, answers the prayers of devout Catholic mothers.

Like the women in the medieval examples above, Silva's Celestina attributes her false miracle to the will of the Christian God. The go-between responds to Areúsa's and Elicia's exclamations of fear and disbelief: «iDad las gracias a Dios que acá tornar me dexó!» (Silva 177). Furthermore, just as Apolonio receives Luciana and the dueñas greet Grima, Areúsa and Elicia react to their surrogate mother's return with fear, followed by joy. Nevertheless, Areúsa's and Elicia's exclamations, highlighted in the following passage, span six pages: a much more extensive, dramatic reception compared to the few verses or paragraphs on the rebirths in the Cantigas, Libro de Apolonio, and Libro del Caballero Zifar: "jAy, válame la Virgen María, no sea algún fantasma que nos quiera matar![...] ¿Y qué hombre pudiera venir a quien yo más quisiera que a ti?[...] jlloro de gozo de te ver[...] cuán perdidas sin ti hemos estado![...] holgarme he contigo, que, en mi ánima, no puedo aún acabar de creer que eres tú[...] ¡Ay, madre!, por cierto, más huelgo yo de tales besar que cuantas manos de galanes puede haver» (Silva 177-178).

Sixteenth-century readers familiar with literary traditions of the thirteenth and fourteenth centuries, as well as biblical stories, would no doubt have considered unorthodox this purportedly miraculous resurrection of a brothel administrator, the opposite of the lady of Galapia and the devout mothers in the cantigas and Libro de Apolonio. Silva increases his go-between's shock value by placing her in the role of the figure happily greeted by her followers after her resurrection from Hell. In the Cantigas, the Virgin intervenes to right a wrong (MacDonald 318). Her interposition in Libro de Apolonio and Libro del caballero Zifar achieves similar results, since the wrongs in these texts include the untimely deaths described above. Viewed as ironically restoring harmony, Celestina's revival contaminates the medieval model of justice, since the go-between's crimes render her an unlikely candidate for the divine intercession that typically results in resurrection. While the protagonist claims that God

6.- Libro de Apolonio, a Byzantine novel, features pagan characters, but medieval writers often recreated classical figures and personas with Christian traits. For instance, Luciana serves the Criador and dresses more like nun than an ancient temple priestess (Monedero 48). 
has brought her back to life to amend past wrongs, many would recognize the famous bawd's hypocrisy when she explains the truth behind her trick: "Todo esto es autorizar más mi persona, estimar más mi fama, dar más crédito a mi poder; porque, habiéndome visto muerta y viéndome agora biva, ¿quién dudará de mis artes?, ¿quién no temerá mis conjuros? ¿A quién faltará esperança en mi saber?[...] A la fe, hijas, pues agora lo podéis decir con razón, que traigo más ciencia que llevé» (Silva 180). The language of authority and power that Celestina employs here even appear to usurp divine authority. In other words, she makes clear that she stages her resurrection not to amend crimes, but to bolster her profile as go-between. The alcahueta thus contrasts with the women in the four earlier texts. In this way, Silva tests the limits of the trope of the Christian God's resuscitation of the Madonna-like lady/mother, or resurrection as reward for saintly femininity or Marian maternity. Here, Celestina legitimizes her experiences in Hell with testimony, while Elicia responds with marvel. Posited this way, the resurrection recalls and inverts the hagiographic ideas of witnessing tied to miracles.

Returning to Silva's time, La Relación que dio Álvar Núnez Cabeza de Vaca (1542) also reworks the medieval resurrection theme in the midst of sixteenth-century censorship practices. In the eight years following their shipwreck off the coast of Florida in 1527, Núñez and several other survivors travelled to the area that currently constitutes the U.S. Southwest where they encountered various indigenous communities. Núñez, who became a healer, claims in one episode to have revived a deceased Native American:

Vinieron muchos indios en busca de Castillo que los curasse y él los encomendó a dios nuestro señor[...] le suplicamos les diessemos salud[...] yo vi que el enfermo que yuamos a curar que estaua muerto[...] estaua mucha gente al derredor del llorando: y su casa desecha que es señal que el dueño está muerto. Y ansí quando yo llegué, hallé el indio los ojos bueltos y sin ningún pulso y con todas señales de muerto. Yo le quité una estera que tenía ençima con que estava cubierto y lo mejor que pude supliqué a nuestro señor fuesse servido de dar salud a aquel y a todos los otros que della tenía necesidad. E después de santiguado y soplado muchas vezes dixeron que aquel que estava muerto y yo avía curado en presençia dellos se avía leuantado bueno y se auía passeado y comido y hablado con ellos y que todos quantos avía curado quedauan sanos[...] esto causo muy gran admiración y espanto y en toda la tierra no se hablaua en otra cosa. Todos aquellos a quien esta fama llegaua nos venían a buscar para 
que los curéssemos y santiguéssemos sus hijos. (Núñez 158-164; emphasis added)

The italicized words in this passage, compared with those from Segunda Celestina, highlighted above, suggest that Núñez's account of the resurrected indio coincides linguistically and thematically with Celestina's rebirth. However, unlike Silva, Núñez recounts a marvelous resurrection with the verisimilitude necessary to convey a truthful account to the Crown: an aspect typical to New World chronicles (López de Mariscal 30-31). As Stephanie Merrim points out, he stresses that the merit of his writing as a gesture of royal service and guide for future travelers was inspired by his observations $(90,93)$. By contrast, Celestina does not purport to relay truthful testimony, but rather, to deceive her listeners. While she fraudulently emphasizes the event's credibility, the text lacks the purported verisimilitude common to medieval and early modern chronicles. Despite her attempt to legitimize her return to the world, Celestina's revival contrasts with the serious tone of Núñez's Relación in that her revival ridicules the Christian resurrection tenet.

Another point of comparison between Núñez's and Silva's texts suggests that the latter parodies a popular literary convention of his time: the "función testimonial» (López de Mariscal 31) communicated by phrases such as "yo he visto.» Common to narratives of discovery and conquest like that of Núñez, the convention also appears in Celestina's resurrection:

CELESTINA. Aquel Sempronio[...] yo lo vi, en los infiernos abrasado.

ELICIA: ¡Qué de cosas deves allá haver visto, en el otro mundo!

AREÚSA. ¡Cómo las deve haver visto!

CELESTINA. He visto, hija, tanto, que no se puede dezir; y agora más tiempo es de descansar de mi camino que de saber nuevas de lo que allá passa.

[ELICIA]. ¡Ay, dinos ahora algo, tía!

AREÚSA. ¿Qué más ha de dezir que verla[...]? ¿Y para qué quieres tú ver ni saber más? (Silva 178-181)

This exchange conveys the idea of Celestina as messenger of incredible events seen in another-if not new-world. In effect, Areúsa and Elicia address their interlocutor as if she had traveled to a distant land: in this case, the afterlife. Here, Celestina legitimizes her experiences in Hell with testimony, while Elicia responds with marvel. As López de Mariscal points out, a singular yo conveys a stronger sense of verisimilitude and testimonial force to perceived extraordinary events than the plural vimos (31). Posited this way, Celestina's resurrection inverts the 
motif of witnessing tied to miracles. In the bawd's revival, the marvelous combines with the ethnographic telling of strange but true events that set the tone in the second part of the Relacion (92). Núñez alerts the reader to incredible but true events: "Lo cual yo escreví con tanta certinidad que aunque en ella se lean algunas cosas muy nuevas y para algunos muy difíciles de creer, pueden sin dubda creerlas» (Núñez 20). The remarkable truth-telling that appears in Núnez's later Relación changes the way the reader may interpret Silva's appropriations of these conventions. Since Celestina returns in a miraculous framework, we may read through a satirical lens her eyewitness reports of her observations in the afterlife. Celestina, like Núñez and other explorers who claimed to witness marvels first hand, bears news from a strange, distant world: in this case, the afterlife. Celestina, a sorceress condemned to hell, is revived in what appears to be a parody of both the miraculous and the marvelous. Such a satire trivializes the seriousness of the allegedly truthful accounts of miracles, parallel to the way the original La Celestina derides sentimental fiction and scholasticism (Iglesias 2009; Canet 2011). Consequently, Segunda Celestina's fictitiousness allows Silva to appropriate La Celestina's practice of inverting tropes, since he depicts a clearly invented miracle. Moreover, he leans on a bestseller's fame to stage his criticism, thereby assuring that his censure reaches a wide audience.

Silva's text also questions obligatory conversion by trivializing the miraculous. Indeed, the bawd's return challenges a pillar of Christianity that was forced upon converts required to make public displays of their acceptance of this belief. Later texts, such as Miguel de Cervantes's "Entremés del retablo de las maravillas» (1615), convey similar reproaches of Old Christian anxiety and hypocrisy. In his entremés, Cervantes addresses the state of contemporary drama and uses the audience's gullibility to question blood purity (Gerli, «El retablo de maravillas» 478). In a story similar to "The Emperor's New Clothes,» the Retablo's onlookers dare not confess they see an empty stage, lest they be taken for one "que tenga raza de confeso" (1086). Indeed, the fear of being labeled a converso was so great that it compelled Old Christians to feign seeing frightening images in accordance with other onlookers. In a similar vein, Silva's parody of resurrection has several functions. The hoax highlights the foolish credulity of those who believe that Celestina has truly risen. The texts thus parody the Inquisitorial reliance on speculation.

Celestina's hoax also transposes miracles and legitimizes the unorthodox. Reconsidering how the bawd reveals her staged resurrection, cited above, shows how Silva aligns black magic-albeit artificial-with authoritative knowledge. The relationship between this magic and the second Celestina's role as a go-between merits commentary. Aside from the lack of true witchcraft, this sequel most notably lacks philocaptio, or a love spell, which some scholars generally consider crucial in La Celestina. In- 
deed, in the original bestseller, Celestina's conjuring of the demon Plutón is her ticket to Melibea's house. In Segunda Celestina, the devil's alleged relationship to the go-between modifies the plot where it should, according to the genre: in the go-between's access to the beloved's home, her mediation on behalf of Felides, and the lovers' union.

QUINCIA. ¡Válala al diablo la vieja! Señora, mala muerte me tome si Celestina, la que resucitó, no está allí.

POLANDRIA. Ay, señora, por tu vida, que suba, y dezirnos ha algo del otro mundo; que muero por vella, que es maravilla. (Silva 311)

In this exchange between lady and servant, a tone of admiration resounds as Silva redeploys Celestina's conjuring in an equally heterodox scene. Polandria's interest in the reborn bawd's eye-witness account is one way in which the alcahueta accesses the lady's house. The go-between highlights the devil's absence from her interview with Polandria; indeed, she describes the visit as a "imaravillosa burla![... ¿ ¿Quién como yo supiera rodear $\tan$ bien y $\tan$ sin sospecha este negocio? ¡Y cómo le hize entender lo que me complía, vendiéndogelo por su provecho, siendo en su daño y mi provecho»! (329). Here, black magic, or at least its surface idea, is an essential part of the plot, as it is in La Celestina. While the witch makes no Satanic pact as in the original bestseller, the devil lingers on the protagonist's entrance to the lady's house via her resurrection.

Because most of the characters in Segunda Celestina believe news of the bawd's return, this false verisimilitude inverts the serious trope of the marvel that remerges in travel narratives and ethnographic accounts. Both Núñez's chronicle and Silva's sequel stem from similar literary traditions: the hagiographic cantiga, Byzantine novel, and novel of chivalry. Silva satirically positions his protagonist as a source of knowledge, or an authority on strange but true events. In this case, the retired prostitute is not only an expert mediator, she is also an authority on another, if not «New,» world, as Areúsa's sacroprofane remark regarding her adoptive mother's glorious knowledge evinces: "iAy tía, señora mía, y qué gran Gloria es oírte dar los consejos y avisos que das a todo el mundo, y la gran abundancia de sabiduría que tienes!» (179). Here Areúsa depicts the bawd as an authority on the afterlife; the irony is abundantly clear to readers aware of the fabricated miracle. Thus, Segunda Celestina subverts serious resurrections, adapting the La Celestina's use of humor to defy mainstream models of knowledge and writing.

This section has compared varied genres of fictional and historical writing to scrutinize how Silva employs language common to hagiographic and chivalrous literature, as well as chronicles of discovery and conquest. In doing so, he satirizes the idea of the revealer of unbeliev- 
able events. Indeed, the second Celestina, with repentance as false as her resuscitation and intentions as sinister as in La Celestina, relies on the other characters' naiveté, as well as the Christian resurrection tenet. Silva inverts tropes in his appropriation of the medieval go-between figure, thus calling into question the social practices that privileged Old Christian lineage to the extreme.

\section{Some Comments on Medina del Campo 1534}

The previous section explored how Silva's resurrection of the go-between functions as a literary and social denunciation. A study of the prints in the earliest conserved edition of Segunda Celestina (Medina del Campo 1534) will now reveal how Silva's comedy in dialogue visually dismantles religious paradigms. ${ }^{7}$ The initials beside the text show how Segunda Celestina visually inverts resurrection themes. Cena X (figure 1) opens with a male figure standing before a cross, beside a creature which, for its halo, appears to be agnus Dei, or the lamb of God. The initial appears below the epigraph: "Felides pregunta a Sigeril si es verdad la resurerecion [sic] de Celestina," and opens the cena in which Felides and his henchmen Sigeril and Pandulfo discuss Celestina's resurrection. Here the three characters employ the inverted trope of eye-witness testimony. The best plot Celestina can weave is one of false saintliness, an idea to which Pandulfo alludes in his descriptions of the untrustworthy fox and the ability to "tornarte de otro pelo" within three days after saintly confession (Silva 205). The resurrected lamb of God contrasts with Celestina's hypocritical resurrection.

FELIDES. ¿Qué cosa es Sigeril? Es verdad que ha resusitado aquella honrrada dueña?

(SIGERIL). Por Nuestra Señora: señor, yo la vi[...] si es fantasma o no no lo sé: mas ver quá santa viene y predicadora no lo podrías creer[...]

7.- Pedro de Mercado appears to be the book's «corrector» as stated in the original longform title listed in the Works Cited page. Pedro Tovans appears at the end of the book as the printer: «Acabóse la presente obra en la muy noble villa de Medina del Campo, en casa de Pedro Tovans en el coral de boeys. Año de M.D. xxxiiij a xxix de Octobre» (583). Joseph Snow's valuable Catálogo de Ilustraciones añadidas did not include these images. He mentions that a 1534 copy of Silva's comedy had recycled blocks from the same series used in Juan Bautista Pedrezano's and Estefano da Sabio's editions of La Celestina, printed in 1531 and 1534, respectively (Snow, "La iconografía» 61). Although Snow does not specify which edition of Segunda Celestina he references, it is unlikely that the reference is to Medina del Campo 1534 , because the only visual material in this copy consists of an elaborate frontispiece, three decorative initial capitals repeated throughout the forty scenes, and three final panels depicting the Assumption. 
PANDULPHO. La major [sic] trama que ella puede tramar es con hipocresía y santidad urdir para texer sus telas, que con este hilado podrá ella mejor urdir tu tela con Polandria que el de las madexas texó el de Calisto y Melibea[...] ¿No sabes[...] que muda la piel la raposa, mas su natural no despoja? ¿No te acontece venirte de confessar un santo y de ay a tres días tornarte de otro pelo? (Silva 205; our emphasis).

The unorthodox text clashes with other prints. The image that inaugurates Cena XVI (figure 2), an initial illustrating a figure possibly shielding his eyes from miraculous light, recalls Christ's appearance to St. Paul. This revelation results in blinding, followed by the saint's conversion to Christianity. Celestina's satirical salvation - that is, her false rebirth and desire for repentance-ironically invert the miraculous revelation pictured in the initial.

Cenas XIV, XVII, and XIX's xylographs all depict the woman shown in figure 3 . Her covered head suggests modesty, while the vessel that she holds could recall myrrh-bearing Saint Martha, whose brother Lazarus was revived by Christ. Alternatively, the object in the figure's hands may draw from Martha's use of holy water to defeat a dragon: a story that appears in Jacobo Vorágine's Legenda áurea (ca. 1260) (410). The hagiographic anthology circulated widely throughout the Iberian Peninsula in the fifteenth and sixteenth centuries, which suggests that printers and readers could have been familiar with the legend (Vorágine 376; Morrás 16). Alluding to Saint Martha thus adds another layer of significance to Silva's text, as the serious witnessing of Christ raising Lazarus from the dead contradicts Celestina's trickster auto-resurrection. The visual that the text evokes through the manto that Pandulfo pays Celestina on behalf of Felides, as well as Celestina's promise to "dar oy cuatro bueltas a mi rosario" (Silva 302), undermine Saint Martha's cloak-covered body, her submissive kneeling posture, and her saintly halo. The serious miraculous image in the historiated initial again clashes with Celestina's hypocritical saintliness: «Si por camino de santidad nos vamos, que somos ya tomados con el hurto" (Silva 306). Baranda notes that this line hails from Celestina's meeting with Melibea, after which the bawd mutters: "Si con el hurto soy tomada, nunca de muerta o encorozada falto, a buen librar» (IV, 86; Silva 306 , note 17). Indeed, the woodcut depicting a model of a saintly feminine figure poses a disjuncture with Celestina's signature false piety.

Cena XV's initial evokes a similar effect if read as a reference to Revelations 10. Figure 4 of a male figure kneeling in prayer before a body of water and a hovering celestial face recalls the biblical story of the resurrected 
Jesus's appearance to disciples by the Sea of Tiberias (Juan 21:1, 4). ${ }^{8}$ Here, another serious rebirth accompanies the story of the revived sorceress, a parallelism that would have been jarring to readers familiar with the biblical tale. Again, Pedro Tovans, the type-setter, has placed a woodcut depicting a serious revelation episode alongside the impious Celestina, perhaps to put an orthodox stamp on the text, to remind readers of a true revelation. This unusual juxtaposition reminds readers of a true Christian miracle in contrast to the false miracle of the text.

The final images in the text - the three engravings of the Virgin Mary placed above a 54 -stanza poem recounting her «Nueva coronacion» (figure 5) - appear at the end of Silva's comedy. The inscription in the center reads: "Assunta es maria sup corum angelorum» (fol. 132r). Once again, the images depicting the Virgin's glorious assumption and the religious poem that they illustrate contrast with varying moments and themes throughout the main body of the text. The crowning of the risen Virgin occurring in the center woodblock may serve as a redemptive counterpart to the textual image of a miter-crowned go-between that the prostitute Palana describes in cena 2: "Como si no supiéssemos aquí quién es Celestina, á cabo de ser coronada tres veces por alcahueta» (Silva 347). The euphemism alludes to the practice of forcing women accused of procuring to wear a type of headdress that resembled a crown or a Bishop's head cover (Baranda 347). Additionally, throughout the Segunda Celesti$n a$, as in Rojas's original, the eponymous protagonist is called "Madre Celestina.» Hence her stand-in daughter, the prostitute Elicia, addresses Celestina, her brothel "mother», as "Madre» (112, auto 3). Similarly, the Pueblo's passage discussed above begins "¡Oh, madre Celestina, ¿qué maravilla tan grande ha sido ésta de tu resurrección?[...] Madre, espantados nos tienes de lo que dizes» (Silva 190-191). The Marian images thus clash with vocative references to Celestina as «madre.»

The final woodcuts also offer an edifying afterward to the comedy's apparently happy ending. Polandria and Felides marry, as do their servants Poncia and Sigeril, and order is restored. This occurs in the final cena, after an exchange between Polandria, Poncia, and Felides concerning Celestina's negative qualities (her sharp tongue and astuteness) vis-a-vis her (few) virtues. Felides compares his union with Polandria as a conversion: "con la gloria del bien que en los braços tengo[...] para más en ti estar convertido[...] que milagrosamente tengo vida» (Silva 568). Polandria appears equally concerned concerned with lineage: «Mañana embíes a pedirme a mi madre en casamiento; $y$ hay un gran bien para ello, y es que yo supe hoy della que la manda que mi padre hizo, que casasse con

8.- «Se manifestó Jesús otra vez a sus discípulos en el mar de Tiberias[...] esta era ya la tercera vez que Jesús se manifestó a sus discípulos, habiendo resucitado de los muertos (Juan 21: 1, 4, ed. Mundo Hispano). 
hombre que fuesse de mi linaje, no pudo perjudicar mi mayorazgo, por cuanto mis agüelos lo dexaron libre de la tal restitución» (Silva 575). In her concluding speech, Poncia instructs Polandria on honor and virtue, linking these qualities to civil obedience and limpieza: «con la virtud se hazen los hombres esentos de las leyes, y por falta de virtud se sujetan a las leyes y punición[...] y con la gloria de haver conservado el previllejo de nuestra limpieza[...] nos vamos a acostar» (Silva 582). The comedy thus ends on an ironic, multi-layered note. On the one hand, the lovers marry outside their caste, as Silva himself did, but which Calisto and Melibea-who some scholars argue to be of disparate linajes (Martínez Miller 101, 107; Bravo-Villasante 1-2) - never achieved. On the other hand, Poncia's didactic conclusion feeds into the images of the virtuous Virgin that continue the edifying tone with which the story of the revived brothel mother ends. Perhaps the Marian images enclose the story in an exemplary message of saintliness and thereby deliver Silva's scandalous comedy and denunciation of practices based on blood purity in a more pious package to readers. This would have been particularly possible because due to the renewed trend in Marianism and the image of the Virgin as the exemplary woman in fifteenth-century Spain (Morrás 13-14).

The initials and the final woodcuts of the Virgin cause Celestina's resurrection to stand out to readers. Indeed, the initial capitals, beside the story of a mock-resurrected sorceress turn into visual manifestations of Christianity's distinguishing tenets-miracles and resurrection-in contrast to the text's sacro-profanity: a combination of mixed messages that again invites a reading of Silva's sequel as one that challenges blood purity. The broken borders around each image suggest that by 1534 the blocks used to create them had already been worn with age, which means that they were likely not cut for Silva's text but had appeared in previous publications. This was common practice, as woodblocks were costly, and printers often reused them in popular works (Norton xix, Lucía Megías 465). Printers had little capital to invest in new printing equipment in sixteenth-century Spain (Lucía Megías 467). Given that the blocks in Medina del Campo 1534 depict miraculous scenes, they were probably recycled. ${ }^{9}$ And yet, although reused blocks may have departed thematically from the text, their predominant position still allowed them to hold a privileged place in the reader's eye. Indeed, they form part of the visual sense of the text, forming an alternative story, even when not historiated (Infantes 94-95, 98). Tovans was a small-scale printer, and very few of his productions survive (Pérez Pastor 481). While the blocks' origins are, therefore, obscure, we do know that he printed a copy of Diego San Pedro's Las siete angustias de nuestra señora, as well as the anonymous A las

9.- Such was the case with caballerías, whose printers often recycled majuscules from liturgical works to copy medieval codices (Lucía Megías 465). 
completas and Despertador de peccadores, and Luis de Montoya's Meditacion de la passion para las siete horas canonicas [sic] in Medina del Campo the same year that he printed Segunda Celestina (UCD Iberian Book project; Mateo Ripoll 455). ${ }^{10}$ Both are possible points of origin for Medina del Campo 1534's woodcuts, which closely resemble those found in the religious texts that Infantes describes in his inventory of early books printed in Spain: Thomas Kempis's, De imitatione Christi (1520), Missale Bendictinum (1521), Las leciones [sic] de Job trobadas por vn reuerendo y deuoto religioso de la orden de los predicadores con vn Infierno de dañados (1524), and Alexandro Anglico's Tractado muy útile [sic] de las obras de misericordia (1530), to name only a few (100-101). The majuscules in these and other works in Infantes' inventory depict hagiographic scenes, including Christ's life and the Assumption (100-103). Just six years after Segunda Celestina's publication, Tovans printed Pedro Ciruelo's Reprobación de supersticiones de hechicerias, which explicitly condemns the type of superstition and black magic, albeit false, featured in Silva's sequel (Mateo Ripoll 443). Tovans's edition of Ciruelo's popular treatise flaunts Juan de Vingles's xylograph designs, which, though much more detailed and ornate than Segunda Celestina's prints, depict similar scenes, such as devoted figures kneeling before Christ's crucifixion (Mateo Ripoll 451).

That Silva's text adopts woodcuts that likely appeared in religious works both before and after 1534 suggests that Segunda Celestina's woodblocks could have been intentionally chosen. The idea is provocative, considering the sacred images beside blasphemous themes that the reader encounters upon engaging with the book. As shocking as it must have been for La Celestina fans to discover that the alcahueta had risen from the dead, the images of saintly figures decorating a deviant story could have been equally as reassuring. Tovans's copies of the tragicomedy printed between 1530 and 1540 further suggest that the woodcuts in Segunda Celestina added shock value and could have resulted in the text being delivered to readers in a more pious package. These editions contain ornamental material commonly used in printed copies of the text (Penney102). The production of this copy coincides with Medina del Campo 1534, which means that Tovans had access to more mainstream La Celestina blocks, none of which appear in the sequel. Printers in the same town sometimes shared materials, and decorated initial capitals were easily sold and lent (Norton xix; Lucía Megías 465, 468). However, other than Nicolás del Piemonte's brief stay in Medina del Campo in 1511 , Tovans appears to have been the only printer in in the town during the first half of the sixteenth-century (Norton xix; Penney 102). For this

10.- No known copy of Tovans' copy of the Meditación de la passion survives. The British Library owns his reproduction of Despertador de peccadores, although no digital edition is available. The Iberian Book projects indicates that the Biblioteca Capitular y Colombina own Las siete angustias de nuestra señora. However, a search in their online catalog yielded no results. 
reason, borrowing or renting La Celestina woodblocks would have been challenging. In other words, instead of visually imitating the bestseller, and further relying on its fame to sell copies of the sequel, the blocks in the Mercado-Tovans edition emulate those found in religious texts. The Marian images and verses do not appear in Venice 1536, Paris/Antwerp 1540, or Paris/Antwerp 1550, nor do the decorated initials. While these image-less editions likely did not shock readers, the xylographs in the earliest surviving edition reinforce the importance of the paradoxical miraculous tone in the text. Regardless of their original circumstances, the images of the Virgin Mary and other saints would seem incongruous to readers accustomed to the diabolic Celestina and her black magic-or the memory thereof-and the heterodox lines and scenes characteristic of both the original La Celestina and the sequel. In this case, the saintly images would most likely have struck readers as paradoxical. The blocks of the Virgin conclude both the exogamous union that "corrects» Calisto and Melibea's forbidden marriage and Poncia's Plautine diatribe on qualities - virtue, meekness, honor, and honesty-that contrast with Celestina's character, thus forming a purifying seal to the contaminated story. The juxtaposition may, therefore, edify and contain the story upon superimposing the pillars of Christianity onto a sacrilegious textual world.

To conclude, the sequel's manifests both visually and thematically what Albert Sicroff described as the impurity that certain Spanish officials sought to eradicate (9). Segunda Celestina's multiple inversions, combined with Rojas's and Silva's ties to the converso community, achieve more than editorial success. This article has suggested that Silva read $\mathrm{La}$ Celestina as a challenge to paradigms, as well as a reaction to marginalization due to prevailing notions of purity and orthodoxy. The sequel's author thus appropriates established notions of impurity and the Christian Resurrection theme through the iconic Iberian figure of the go-between. The revival of the murdered go-between trivializes key events in La Celestina-namely, the deaths of Celestina and the central characters - to invert conventional literary tropes and prevailing socio-religious paradigms. If the state considered a perceived stained ancestry a threat to religious homogeneity, Silva's text challenges social, religious, and literary hierarchies via a metaphorical contamination. By undoing key moments in La Celestina's plot, the sequel appropriates the original bestseller's interrogation of literary models for which Canet and Iglesias have argued. Silva thus maintains enough fidelity to the original text to continue the bawd's story, while simultaneously contaminating and subverting it. The points of similarity with medieval and contemporaneous travel writing that I have demonstrated reveal that Celestina's renewal, juxtaposed against the serious, religious woodcuts within the Pedro del Mercado edition, gives an additional diabolic twist to the important biblical theme of miracles. Examining the ways that Silva's sequel calls into 
question the notion of blood purity and the dominant Catholic doctrine has highlighted the mutually productive relationship between La Celesti$n a$ and Segunda Celestina, as well as the ways in which the text dialogues with other literature possibly influenced by the social climate of the time.

\section{List of Figures}

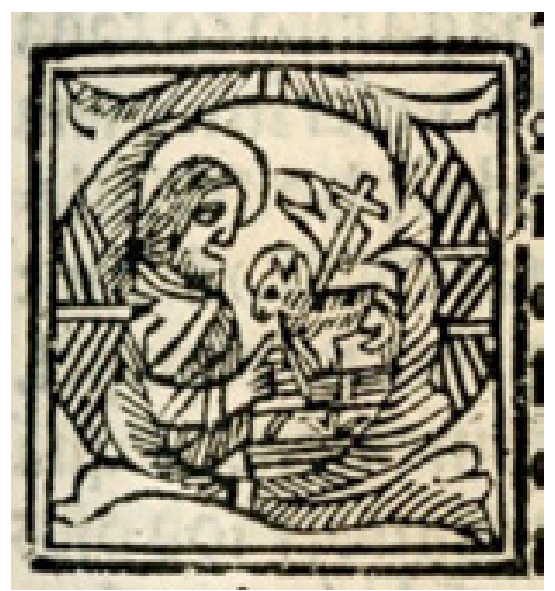

Fig. 1. Decorated initial depicting Christ/agnus dei (Courtesy of the Hispanic Society of America, New York)

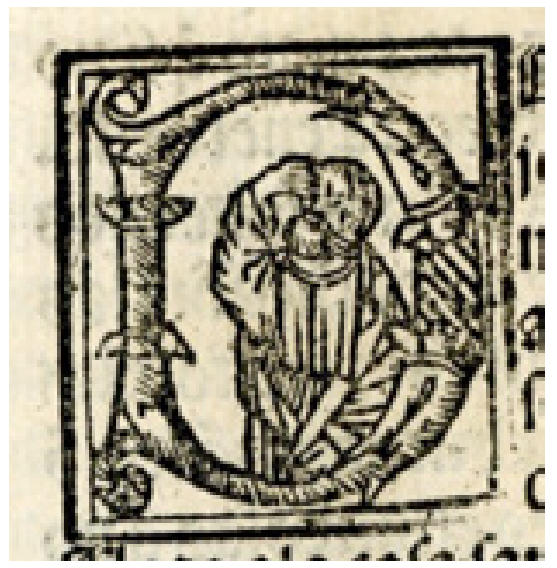

Fig. 2. Decorated initial depicting St. Paul (Courtesy of the Hispanic Society of America, New York) 


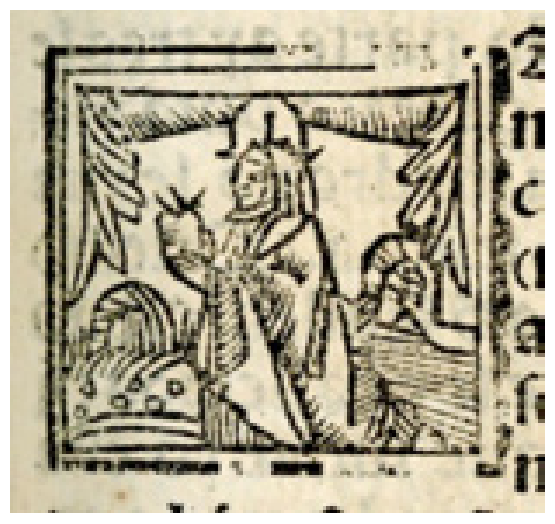

Fig. 3. Decorated initial depicting St. Martha (Courtesy of the Hispanic Society of America, New York)

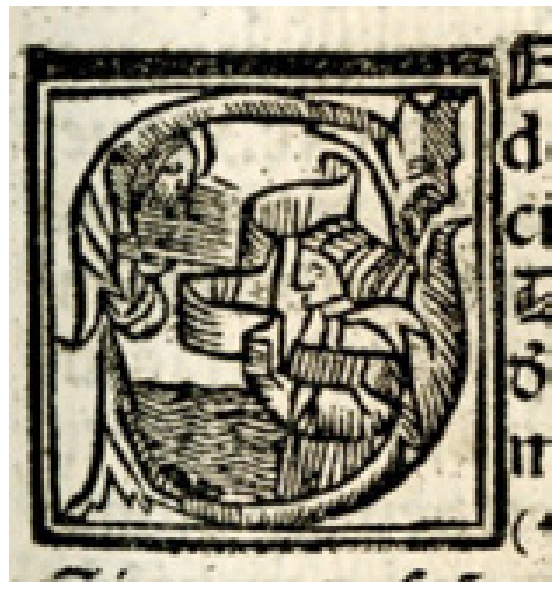

Fig. 4. Decorated initial depicting Revelations scene (Courtesy of the Hispanic Society of America, New York) 


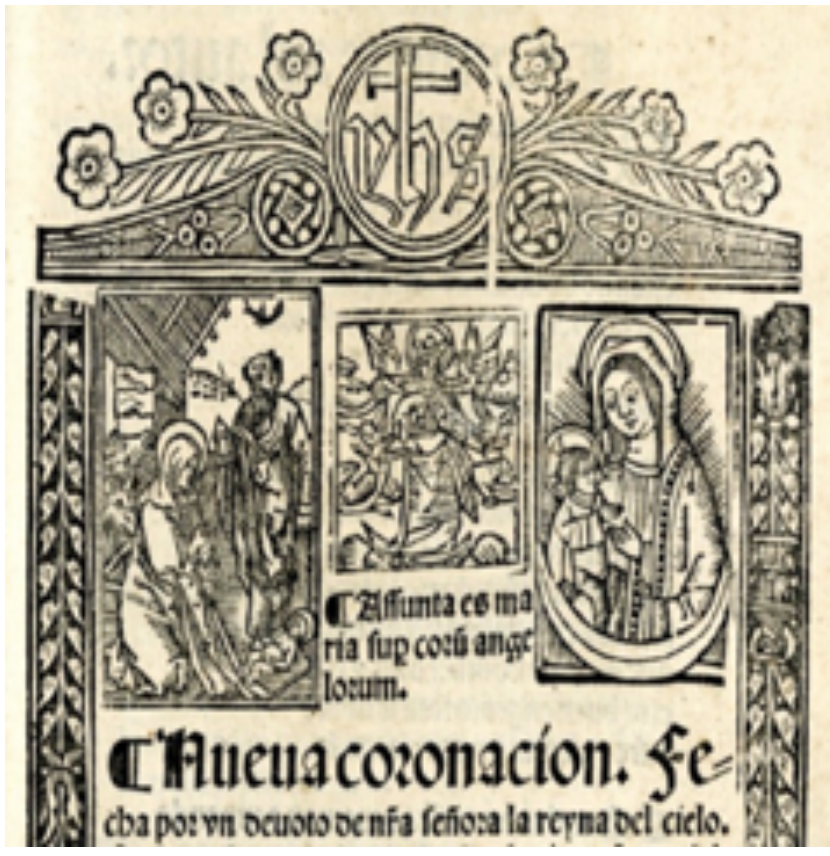

Fig. 5. Woodcuts depicting the Assumption from «Nueva coronación» (Courtesy of the Hispanic Society of America, New York)

\section{Works Cited}

Alfonso X, «el Sabio,» King of Castile and León. Calila e Dimna. Ed. Alberto Cacho Blecua and María Jesús Lacarra. Madrid, Castalia, 1985.

—. Cantigas. Ed. Jesús Montoya. Madrid: Cátedra, 1988.

-. Cantigas de Santa María (cantigas 1 a 100). Edición de Walter Mettmann. Madrid: Castalia, 1986.

-. Songs of Holy Mary. Ed. Connie L. Scarborough. Tempe: Arizona Center for Medieval and Renaissance Studies, 2000.

Anglico, Alexandro. Tractado muy útile [sic] de las obras de misericordia. Medina del Campo: Pedro Tovans, 1530.

Baranda, Consolación. Introduction. Segunda comedia de la Celestina. By Feliciano de Silva. Ed. Consolación Baranda. Madrid: Cátedra, 1988.

Bravo-Villasante, Carmen. "Otra interpretación de La Celestina.» Ínsula, vol. 14, 1959, pp. 1-2.

Cervantes y SaAvedra, Miguel de. "Entremés del retablo de las maravillas.» Obras completas. Vol. 2. Ed. Juan Carlos Peinado. Madrid: Cátedra, 2005. 
Comedia de Calisto y Melibea. Burgos: Fadrique de Basilea, 1499.

Comedia de Calisto y Melibea. Ed. José Luis Canet. Valencia: Publicaciones de la Universitat de Valencia, 2011.

Da Costa Fontes, Manuel. The Art of Subversion in Inquisitorial Spain: Rojas and Delicado. West Lafayette: Purdue University Press, 2005.

Delicado, Francisco. Retrato de a Lozana Andaluza. Ed. Jacques Joset and Folke Gernet. Madrid: Real Academia Española, 2013.

Despertador de peccadores. Medina del Campo: Pedro Tovans, 1534.

Dopico-Black, Georgina. Perfect Wives, Other Women: Adultery and Inquisition in Early Modern Spain. Durham: Duke University Press, 2001.

Fernández MARTín, Luis. "Feliciano de Silva y el movimiento comunero en Ciudad Rodrigo.» Archivos Leoneses, 62 (1977), pp. 285-237.

GaGliardi, Donatella. "La Celestina en el Índice: argumentos de una censura.» Celestinesca, vol. 31, 2007, pp. 59-84.

GerLI, Michael. Celestina and the Ends of Desire. Toronto: University of Toronto Press, 2011.

—. "El retablo de las maravillas: Cervantes's 'Arte nuevo de deshacer comedias». Hispanic Review, 57-4 (1989), pp. 477-92.

Gilman, Stephen. The Spain of Fernando de Rojas: The Intellectual and Social Landscape of «La Celestina.» Princeton: Princeton University Press, 1972.

Gómez-Bravo, Ana María. Textual Agency: Writing Culture and Social Networks in Fifteenth-Century Spain. Toronto: Toronto Iberic, 2013.

Green, Otis. "The Celestina and the Inquisition.» Hispanic Review, 15-1 (1947), pp. 211-216.

-. "Additional Note on the Celestina and the Inquisition.» Hispanic Review, 16-1 (1948), pp. 70-71.

Hamilton, Michelle. Representing Others in Medieval Iberian Literature. New York: Palgrave MacMillan, 2007.

HinRichs, William. The Invention of the Sequel. Expanding Prose Fiction in Early Modern Spain. Woodbridge: Támesis, 2011.

HomzA, Lu Ann. The Spanish Inquisition, 1478-1614: An Anthology of Sources. Indianapolis: Hackett Publishing Company, Inc., 2006.

IGLESIAS, Yolanda. "Aspectos legales y sociales del matrimonio: un acercamiento desde La Celestina y sus continuadores.» Revista canadiense de estudios hispánicios, 38-3 (2014), pp. 467-484.

- Una nueva mirada a la parodia de la novela sentimental. Madrid: Iberoamericana-Vervuert, 2009.

Illades Aguilar, Gustavo. Fernando de Rojas y el taller salamantino. México, D.F.: Universidad Nacional Autónoma de México, Instituto de Investigaciones Filológicas, 1999.

INFANTES, Víctor. Del libro aúreo. Madrid: Calambur Editorial, S.L., 2006.

Kamen, Henry. Spain, 1469-1714: A Society of Conflict. New York: Longman, 1983. 
KaPLAN, Gregory. "Landscapes of Discrimination in Converso Literature.» Place, Space, and Landscape in Medieval Narrative, edited by Laura Howes, University of Tennessee Press, 2010, pp. 121-137.

Kathleen Kulp-HiLl, translator. Alfonso X, "El Sabio,» King of Castile and León: Songs of Holy Mary. Ed. Connie L. Scarborough. Tempe: Arizona Center for Medieval and Renaissance Studies, 2000.

Kimmel, Seth. Parables of Coercion. Chicago: University of Chicago Press, 2015.

Kempis, Thomas. De imitatione huius mundi et de contemptus omnium. Miguel de Erguía: Alcalá de Henares, 1520.

La Celestina. Ed. Dorothy Severin. 3rd ed. Madrid: Alianza Editorial, 2013.

LEA, Henry Charles. A History of the Inquisition of Spain. Vol. 1, 2. New York: The Macmillan Company, 1908.

LidA DE MAlKiel, María Rosa. La originalidad artística de "La Celestina.» Buenos Aires: Editorial Universitaria de Buenos Aires, 1962.

-. "Reorienting medieval Spanish Travel Narratives." Yearbook of Comparative and General Literature, 52 (2006), pp. 19-28.

López De MARISCAL, Blanca. La escritura y el camino: discurso de viajeros en el Nuevo Mundo: artículos reunidos. México, D.F.: Bonilla Artigas Editores, 2014.

Lucía Megías, José Manuel. Imprenta y libros de caballerías. Madrid: Ollero y Ramos, 2000.

Libro de Apolonio. Ed. Carmen Monedero. Madrid: Castalia, 1987.

Libro del caballero Zifar. Ed. Cristina González. Madrid: Cátedra, 1983.

MacDonald, R.A. "Alfonsine Law, the Cantigas, and Justice." Studies on the Cantigas de Santa Maria: Art, Music, and Poetry: Proceedings of the International Symposium on the "Cantigas de Santa Maria" of Alfonso X, el Sabio (1221-1284) in Commemoration of Its 700th Anniversary Year-1981, edited by Israel J. Katz and John E. Keller, Madison, Medieval Seminar, 1987, pp. 314-328.

Márouez, Francisco. Orígenes y sociología del tema celestinesco. Barcelona: Editorial Anthropos, 1993.

Maravall, José Antonio. El mundo social de "La Celestina." Madrid: Editorial Gredos, 1968.

MarTínez, María Elena. «Interrogating Blood Lines: Purity of Blood,' the Inquisition, and Casta Categories." Religion in New Spain, edited by Susan Schroeder and Stafford Poole, Albuquerque, University of New Mexico Press, 2007, pp. 196-217.

Martínez de Bujanda, Jesús. Index de livres interdits: Index espagnols 1551, 1554, 1559.Vol. 5. Sherbrooke: Centre d'études de la Renaissance, Université de Sherbrooke, 1993.

Martínez Miller, Orlando. La ética judía y "La Celestina" como alegoría. Miami: Ediciones Universal, 1978. 
Merrim, Stephanie. "The first fifty years of Hispanic New World historiography: The Caribbean, Mexico, and Central America.» Cambridge History of Latin American Literature. Vol. 1. Discovery to Modernism, edited by Roberto González Echevarría and Enrique Pupo-Walker, Cambridge University Press, 1996, pp. 58- 100.

Missale Bendictinum. Medina del Campo: Pedro Tovans, 1521.

Monedero, Carmen. Introduction and notes. Libro de Apolonio, edited by Carmen Monedero. Madrid: Castalia, 1987.

Morrás, María. "Ser santa y mujer (Península Ibérica, Siglos XV-XVII)». Medievalia, 18-2 (2015), pp. 9-24.

Norton, Frederick .J. A Descriptive Catalogue of Printing in Spain and Portugal, 1501-1520. New York: Cambridge University Press, 1978.

Nueva coronación. Fecha por un devoto de nuestra señora la reyna del cielo. Fecha y compuesta por diuina tehologia: enl a qual se contiene de la forma y condición que esta reyna de los angeles fue assumpta y subida sobre los coros angélicos. Item mas cuenta como loas nueue ordenes dellos angeles y gerarchias reciben a su reyna: y lo que dize cada vno. Assi mismo cuenta delos instrumentos que tocan en sus bodas virginales. Medina del Campo: Pedro Tovans, 1534.

Núñez Cabeza de VACA, Álvar. La Relación que dio Álvar Núñez Cabeza de Vaca in Núnez Cabeza de Vaca: His Account, Life, and the Expedition of Pánfilo de Narváez, vol. 1, edited by Rolena Adorno and Patrick Charles Pautz, University of Nebraska Press, 1999.

Olsen, Marilyn. "Hacia un concepto de la riqueza en el Libro del cauallero Cifar: la aventura de Galapia.» Encuentros y desencuentros de culturas: desde la edad media al siglo XVIII. Actas Irvine, vol. 92, 1982, pp. 20-24.

Penney, Clara Louise. The Book Called "Celestina" in the Library of the Hispanic Society of America. New York: Hispanic Society of America, 1954.

Pérez PAstor, Cristóbal. La imprenta en Medina del Campo. Madrid: Sucesores de Rivadeneyra, 1895.

Perugini, Carla. "Delicado, Francisco: La Lozana andaluza." Diccionario filológico de literatura española, Siglo XVI, edited by Pablo Jauralde Pou, Castalia, 2009, pp. 343-346.

Real Academia Española. Diccionario de autoridades. Madrid: Gredos, 1990.

- Diccionario de la lengua española. 22 October 2016.

REDFIELD, Robert. "La resurrección y la ascensión de Jesucristo en el Poema de mío Cid.» La Corónica, 15-1 (1986-87), pp. 77-79.

Ripoll, Verónica Mateo. "Sobre una edición ignota de Reprobación de supersticiones del maestro Ciruelo.» Dynamis, 22 (2002), pp. 437-459.

Silva, Feliciano de. Segunda comedia de la Celestina. Ed. Consolación Baranda. Madrid: Cátedra, 1988.

- Segunda comedia de la Celestina, en la qual se trata de los amores de un cavallero llamado Felides, y de una donzella de clara sangre llamada Polandria. Antwerp, Paris: 1540. Houghton Library, Harvard University. 
Silva, Feliciano de. Segunda comedia de la Celestina: en lo quall se trata de los amores de vn cauallero llamado Felides: y de vna doncella de clara sangre llamada Polandria. Donde pueden salir para los que lieren muchos y grandes auisos que della se pueden tomar. Derigida y endreçada al muy excelente e illustrissimo señor: don Francisco de çuñiga guzman: y de Sotomayor. Duque de Bejar: maros de' Ayamonte y de Bibraleon. Conde de Belalcalçar y de Bañares. Señor de la puebla Alcocer con todo su vizcondado y dellas villas de Lepe: Burguillos y Capilla y justicia mayor d' Castilla. La qual comedia fue corregida y emendada por el muy noble cauallero Pedro d'Mercado: vezino y morador en la nobla villa de Medina del Campo. Ed. Pedro del Mercado. Pedro Tovans: Medina del Campo, 1534.

- Segunda comedia de la famosa Celestina en la qual se trata de la Resurrection de la dicha Celestina y de los amores de Felides y Polandria corregida y emendada por Domingo de Gaztelu secretario del Ilustrissimo Señor don Lope de Soris embaxador Cesareo acerca la Illustrissima Señoria de Venecia: Año de 1536 en el mes de Junio. Ed. Domingo de Gaztelu. Venice: Estephano da Sabio, 1536.

- Segunda Comedia de Celestina en la qual se trata de los amores de un cauallero llamado Felides: y de vna doncella de clara sangre llamada Polandria, Donde pueden salir para los que leyeren muchos y grandes avisos que della se pueden tomar Agora nuevamente impressa y corregida: Dirigida al muy illustrisimo señor Don Francisco de çuñiga guzman: y de Sotomayor. Duque de Bejar: maros de' Ayamonte y de Bibraleon \&c. Conde de Belalcalçar y de Bañares. Paris? sold at Anuers, ca. 1550.

SNow, Joseph. "Ilustrando a Celestina en Celestinesca, 1976 a 2002: Un catálogo». Celestinesca, 39 (2015), pp. 329-356.

-. «La gran Celestina, ahora en versión de José Luis Gómez.»Celestina, de Fernando de Rojas. Madrid: Compañía Nacional de Teatro Clásico, 2016: (14-51).

- La iconografía de tres Celestinas tempranas (Burgos, 1499; Sevilla, 1518; Valencia, 1514): Unas observaciones.» Estudios sobre "La Celestina,» edited by Santiago López-Ríos, Madrid, Istmo, 2001, pp. 56-82.

Solomon, Michael and Juan Carlos Temprano. "Modos de percepción histórica en el 'Libro de Alexandre.'» Inti: Revista de literatura, 15-1 (1982), pp. 2-24.

TiCKNor, George. History of Spanish Literature. Vol. 2. New York: Harper and Brothers, 1849.

UCD. Iberian Book Project. The Centre for the History of the Media at University. 29 March 2016.

Vorágine, Jacobus. Legenda áurea. Ed. Eamon Duffy. Princeton: Princeton University Press, 2012. 